The IAB-ISBA 'Guidelines on the Payment for Editorial Content to Promote Brands within Social Media', a revised version of which was published in July 2012, are a good benchmark.

\title{
References
}

- http://www.asa.org.uk/ASA-action/Adjudications/2012/7/Toni-andGuy-(Lakeside)-Ltd/SHP_ADJ_193054.aspx

- http://www.oft.gov.uk/OFTwork/consumer-enforcement/consumerenforcement-completed/handpicked_media/

- http://www.asa.org.uk/ASA-action/Adjudications/2012/6/Nike-(UK)Ltd/SHP_ADJ_183247.aspx

- http://www.asa.org.uk/ASA-action/Adjudications/2012/3/MarsChocolate-UK-Ltd/SHP_ADJ_185389.aspx

- http://www.iabuk.net/sites/default/files/IAB\%20ISBA\%20Guideline s\%20on\%20the\%20Payment\%20for\%20Editorial\%20Content $\% 20$ $\% 20$ July\%202012.pdf

Thomas Spanyol, Trainee, Osborne Clarke, London Email: Thomas.spanyol@osborneclarke.com

\section{Rise in complaints about unsolicited calls}

Journal of Direct, Data and Digital Marketing Practice (2012) 14, 171-172. doi:10.1057/dddmp.2012.32

Topic: Telemarketing

Who: BBC (Panorama), Ofcom, ICO and the DMA

When: June/July 2012

Where: UK

Law stated as at: 7 August 2012

\section{What happened}

A recent edition of the BBC's 'Panorama' current affairs programme focused on cold callers breaching UK 'do not call' laws ('DNC laws') with apparent impunity.

This was followed closely by a worrying finding in the Information Commissioner's Annual Report for 2011/2012 that complaints about unsolicited marketing calls and texts had shot up by 43 per cent compared to the previous year.

Over 7000 complaints

The Information Commissioner's Office (ICO) had logged nearly 7,100 complaints in 2011/2012, but there was little sign of any significant enforcement action having been taken. Going forward, however, the Information Commissioner did report the setting up of a team dedicated to the enforcement of the regulations that include the 
Penalties possible since 2003
DNC laws, the Privacy and Electronic Communications (EC Directive) Regulations 2003 ('PECRs').

'About time too' one might comment as the PECRs have been around for just short of 9 years and are the most important single set of marketing laws in the UK after the unfair commercial practices regulations.

But why this apparent lack of appetite for bringing DNC law violators to book?

\section{DMA fields 'do not call' law questions}

The question was put in media interviews after the Panorama programme to the Direct Marketing Association ('DMA'). The DMA runs the UK's 'do not call' system or Telephone Preference Service ('TPS') as it is called in the UK, under contract to Ofcom.

In response, the DMA pointed out that ever since the DNC laws were first introduced, ICO has had powers to take enforcement action and seek monetary penalties against those flouting the rules, based on the evidence supplied to them by the DMA.

This is correct. Up until recently it has been theoretically possible for ICO to seek the imposition of fines of up to $£ 5,000$ on those found to flout DNC laws. This upper limit has since been increased to $£ 500,000$ in serious cases, but still no reports have been published of action being taken against telemarketers for breaching DNC laws.

\section{Why this matters}

Following the Panorama broadcast, registrations of telephone numbers with the TPS spiked to no less than 11,000 in a single day compared to an average of around 2,000 on a normal day.

This clearly demonstrates public awareness and concern, but if no meaningful action is being taken to enforce the rules it is hardly surprising that irresponsible telemarketers like those highlighted in Panorama are making hay.

Looking ahead, however, it appears from ICO's latest indications that their attitude towards DNC law breaches is hardening.

Telemarketers should take note, therefore, and ensure that the TPS rules are followed. Numbers should be checked against the opted-out list before campaigns are started. Then calls should not be made to any numbers that appear on the TPS list unless, to quote the statutory exception in the PECRs, the owner of the number has 'notified a caller that he does not, for the time being, object to such calls being made on that line by that caller'.

Stephen Groom, Head of Marketing and Privacy Law, Osborne Clarke, London

Email: stephen.groom@osborneclarke.com 